\title{
Upaya Meningkatkan Hasil Belajar IPA Pada Materi Sifat-Sifat Cahaya Menggunakan Media Video Pembelajaran
}

\author{
Rusi Rusmiati Aliyyah ${ }^{1}$, Saraswati ${ }^{2}$, Sri Wahyuni Ulfah ${ }^{3}$, Subaiki Ikhwan ${ }^{4}$ \\ ${ }^{12}$ Pendidikan Guru Sekolah Dasar, Fakultas Keguruan dan Ilmu Pendidikan, Universitas \\ Djuanda, Jalan Tol Ciawi No 01 Kode Post 16720, Bogor, Jawa Barat \\ ${ }^{3}$ Pendidikan Dasar, Sekolah Pascasarjana Universitas Pendidikan Indonesia, \\ Jl. Dr. Setiabudhi No.229, Cidadap, Isola, Sukasari, Isola, Kec. Sukasari, Kota Bandung, \\ 40154, Jawa Barat \\ ${ }^{4}$ Sekolah Tinggi Agama Islam Nurul Iman, Jalan Warujaya, Parung, Bogor, 16330, Jawa \\ Barat \\ E-mail: rusi.rusmiati@unida.ac.id \\ Telp: 08176395090
}

Received: 12 Januari 2021; Revised: 26 Februari 2021; Accepted: 28 April 2021

DOI: http://dx.doi.org/10.37905/aksara.7.2.317-326.2021

\begin{abstract}
Abstrak
Penelitian bertujuan untuk mengetahui peningkatan hasil belajar IPA materi sifat-sifat cahaya menggunakan media video pembelajaran. Menggunakan pendekatan Penelitian Tindakan Kelas (PTK) dengan model Kemmis MC Taggart. Data diambil melalui observasi, test, wawancara dan dokumentasi. Indikator keberhasilan penelitian adalah $80 \%$ siswa mencapai KKM sebesar 70 . Hasil pra siklus menunjukan hanya 14 siswa (46.7\%) yang memiliki nilai 70 sesuai KKM. Siklus pertama menghasilkan $22(73.3 \%)$ siswa mendapatkan nilai minimal 70, sedangkan pada siklus kedua sebanyak 25 (83.3\%) siswa yang memiliki nilai sesuai KKM. Dengan demikian, terjadi peningkatan $27 \%$ dari nilai prasiklus ke siklus I, dan 10\% dari siklus I ke siklus II.
\end{abstract}

Kata Kunci: Media Pembelajaran, Penelitian Tindakan Kelas, Sekolah Dasar

\section{Abstract}

This study aims to determine the increase in science learning outcomes in light's material properties using instructional video media. Using a Classroom Action Research (CAR) approach with the Kemmis MC Taggart model. Data were collected through observation, tests, interviews, and documentation. The indicator of research success is that $80 \%$ of students reach a KKM of 70 . The pre-cycle results show that only 14 students $(46.7 \%)$ have a score of 70 , according to the KKM. The first cycle resulted in $22(73 \%)$ students getting a minimum score of 70 , while in the second cycle, there were $25(83 \%)$ students who had scores according to the KKM. Thus, there was an increase of $27 \%$ from the pre-cycle value to cycle I and $10 \%$ from cycle I to cycle II.

Keywords: Learning Media, Classroom Action Research, Elementary School

\section{PENDAHULUAN}

Pendidikan merupakan salah satu faktor terpenting bagi manusia untuk menjalani kehidupan. Dalam Undang-Undang No.20 Tahun 2003 tentang Sistem 
Pendidikan Nasional Pasal 1 bahwa Pendidikan adalah usaha sadar dan terencana untuk mewujudkan suasana belajar dan proses pembelajaran agar peserta didik secara aktif mengembangkan potensi dirinya untuk memiliki kekuatan spiritual keagamaan, pengendalian diri, kepribadian, kecerdasan, akhlak mulia, serta keterampilan yang diperlukan dirinya, masyarakat, bangsa dan negara (Kemendikbud, 2003). Pendidikan merupakan suatu yang memiliki peran penting dalam menghasilkan sumber daya manusia yang berkualitas. Pendidikan adalah suatu proses yang memiliki tujuan yang umumnya menciptakan dan membangun pola-pola tingkah laku pada kanak-kanak atau orang yang dididik (Siahaan, 2016).

Dalam pendidikan tentunya terdapat suatu proses pembelajaran untuk mencapai suatu tujuan pembelajaran yang telah ditentukan oleh guru yang disesuaikan dengan karakteristik siswa. Proses pembelajaran merupakan salah satu faktor yang paling utama dalam proses mengajar. Dalam proses belajar mengajar guru dan siswa memiliki kesulitannya masing-masing (Anugraheni, 2017). Pembelajaran adalah proses yang memfasilitasi peserta didik agar dapat belajar dengan baik dan nyaman, sehingga mendapatkan proses pembelajaran yang efektif sebagaimana yang diinginkan (Hanafy, 2014). Pembelajaran IPA sebaiknya dilakukan degan pembelajaran yang dapat menyiapkan peserta didik untuk melek Ilmu Pengetahuan Alam dan Teknologi, maupun berpikir logis, kritis serta kreatif (Rahayuni, 2016). Ilmu Pengetahuan Alam adalah salah satu mata pelajaran utama pada kurikulum pendidikan di Indonesia, termasuk dalam jenjang sekolah dasar. Pembelajaran IPA adalah pembelajaran berdasarkan pada prinsip-prinsip, proses yang dapat menumbuhkan perilaku ilmiah siswa terhadap konsep-konsep IPA (Susanto, 2013). Sedangkan hasil belajar adalah suatu proses yang dilakukan seseorang setelah melakukan kegiatan belajar, hasil belajar meliputi ranah kognitif, afektif, maupun psikomotorik yang diambil dari data penilaian guru (Aliyyah. et all, 2017). Hasil belajar adalah puncak dari kegiatan belajar yang menghasilkan perubahan dan pengetahuan (kognitif), sikap (afektif), dan keterampilan (psikomotorik) yang berkesinambungan dan dinamis serta dapat diukur dan diamati (Pangestu et al., 2015).

Fakta di lapangan, pembelajaran IPA masih banyak sekali yang menganggap sulit bagi siswa dari jenjang sekolah dasar sampai menengah. Hal ini terbukti dari hasil data dan wawancara pada Guru kelas IV SDN Kampung Bulak terdapat hasil belajar IPA siswa kelas IV materi sifat-sifat cahaya yang masih rendah dan belum mencapai kriteria ketuntasan minimal yang telah ditentukan sekolah yaitu minimal 70. Dari 30 jumlah siswa terdapat $73 \%$ yang tidak memenuhi KKM serta yang memenuhi KKM hanya $27 \%$ pada kelas IV SDN Kampung Bulak.

Dengan demikian, pada pembelajaran IPA materi sifat-sifat cahaya di kelas IV terdapat beberapa permasalahan, yaitu terdapat 22 siswa yang kurang paham dengan materi-materi IPA dan kurangnya penggunaan media pembelajaran yang digunakan saat pembelajaran, karena guru hanya menggunakan media 1 kali saja dalam materi sifatsifat cahaya.

Dari permasalahan di atas, peneliti berusaha untuk melakukan perubahan pada proses pembelajarannya yaitu dengan menggunakan media video pembelajaran, karena video pembelajaran akan membantu siswa dalam memahami pembelajaran IPA materi sifat-sifat cahaya, baik dalam jarak jauh maupun dekat untuk meningkatkan kualitas proses dan hasil pembelajaran. 
Media pembelajaran yang mengintegrasikan mata pelajaran dapat memberikan motivasi siswa dalam belajar dan prestasi belajar (Astuti et al., 2020). Video dalam pembelajaran memungkinkan untuk mengatasi kendala dunia nyata dan mengeksplorasi yang dapat disediakan dari ruang digital Video adalah gambar yang bergerak. Jika objek pada animasi adalah buatan, maka objek pada video adalah nyata. Video adalah gambar hidup yang mempunyai tampilan visual dan audio Video yaitu berkenaan dengan apa yang dapat dilihat, utamanya adalah gambar hidup baik bergerak atau motion, proses perekamannya, dan penayangannya yang tertentunya melibatkan teknologi (Busyaeri et al., 2016).

Penelitian ini melanjutkan penelitian yang berjudul "Peningkatan Hasil Belajar IPA Siswa Kelas VI Melalui Media Pembelajaran Video Pada Tema 6 dan 7 Topik Biologi" karena hasil belajar IPA meningkat setelah menggunakan video pembelajaran yaitu 80,56\% (Iriani, 2019).

Berdasarkan latar belakang masalah tersebut di atas, maka penelitian ini perlu dilakukan untuk mengetahui bagaimana upaya meningkatkan hasil belajar IPA pada materi sifat-sifat cahaya dengan menggunakan media video pembelajaran di kelas IV SDN Kampung Bulak Bogor.

\section{METODE}

\section{Jenis Penelitian}

Penelitian ini menggunakan pendekatan Penelitian Tindakan Kelas (PTK) yang bertujuan untuk memberikan pembelajaran yang dapat meningkatkan hasil belajar peserta didik dengan menggunakan media video pembelajaran (Sari et al., 2020). Penelitian dirancang dengan menggunakan model Kemmis dan MC Taggart berdasarkan siklus dengan tahapan sebagaimana berikut:

Pertama, Tahap Perencanaan. Kegiatan yang dilakukan pada tahap perencanaan yaitu: (1) Peneliti bersama guru melakukan wawancara dan berdiskusi untuk mengetahui gambaran awal terkait materi pembelajaran yang dirasa sulit sehingga terjadi rendahnya hasil belajar siswa dan upaya yang dilakukan yaitu dengan melakukan pembelajaran materi magnet dengan menggunakan media video pembelajaran. (2) Rencana Pelaksanaan Pembelajaran (RPP), (3) Penyiapan media video pembelajaran, (4) Soal lembar kerja siswa, (5) Soal Evaluasi dan Lembar observasi.

Kedua, Tahap Pelaksanaan. Kegiatan yang dilakukan pada tahap pelaksanaan yaitu: (1) Menjelaskan materi pembelajaran tentang sifat-sifat cahaya, (2) Guru menampilkan video pembelajaran mengenai sifat-sifat cahaya, (3) Guru melakukan diskusi dengan siswa, (4) Guru menjelaskan tugas yang harus dikerjakan setiap siswa dan membagikan lembar kerja siswa yang sudah dipersiapkan guru.

Ketiga, Tahap Observasi. Pada tahap ini, yang harus dilakukan adalah mengamati perilaku siswa dalam mengikuti proses pembelajaran dan mengamati pemahaman siswa terhadap penguasaan materi yang telah dirancang sesuai dengan tujuan PTK.

Keempat, Tahap Refleksi. Pada tahap ini, peneliti mencatat hasil observasi, mengevaluasi hasil observasi, menganalisis hasil pembelajaran, mencatat kelemahankelemahan untuk dijadikan bahan penyusunan rancangan siklus beirkutnya, sampai tujuan PTK tercapai. 
Adapun gambar model penelitin tindakan kelas yang digunakan dalam penelitian ini sebagaimana gambar 1 .

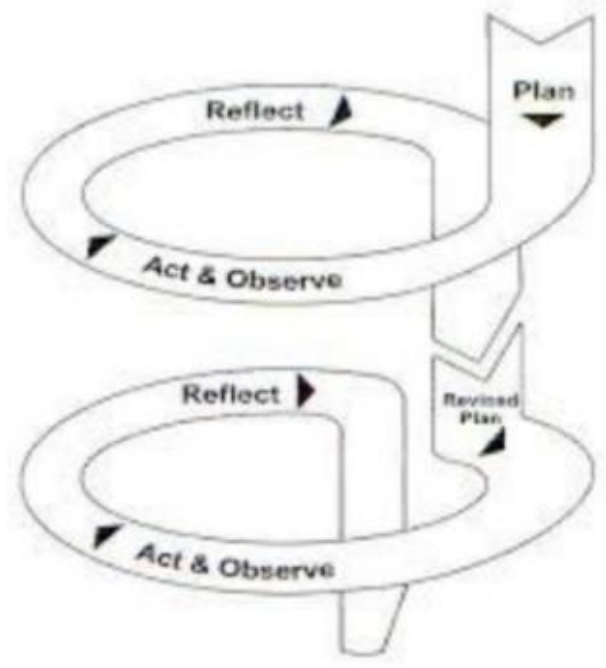

Gambar 1 Model Kemmis dan MC Taggart.

Sumber: (Aliyyah et al., 2019)

\section{Tempat, Subyek dan Waktu Pelaksanaan Penelitian}

Penelitian dilaksanakan pada siswa kelas IV-A SDN Kampung Bulak dengan jumlah siswa 30 orang yang terdiri dari 22 siswa laki-laki dan 8 siswi perempuan. Adapun kegiatan penelitian dilaksanakan pada bulan Oktober sampai dengan Desember 2020.

\section{Indikator Keberhasilan}

Indikator keberhasilan pelaksanaan penelitian ini dinyatakan berhasil manakala hasil belajar siswa pada materi sifat-sifat cahaya meningkat dan mencapai $80 \%$ dari keseluruhan siswa dengan nilai sama dengan atau diatas Kriteria Ketuntasan Minimal (KKM) yaitu 70 .

\section{Teknik dan Prosedur Pengumpulan data}

Adapun teknik pengumpulan data yang digunakan dalam penelitian ini adalah: (1) Observasi, dilakukan dengan mendatangi langsung sekolah serta mengikuti proses pembelajaran melalui Zoom Meeting dan luring. Observasi ini dilakukan secara kolaboratif oleh pengajar (peneliti) dan dibantu oleh guru kelas yang bertugas sebagai observer. Kegiatan ini dilakukan untuk mengamati pelaksanaan dan perkembangan pembelajaran yang dilakukan guru dan siswa pada pembelajaran IPA tentang sifat-sifat cahaya dengan menerapkan media video pembelajaran. (2) Tes adalah alat pengukuran berupa pertanyaan, perintah, dan petunjuk yang ditunjukkan kepada tester untuk mendapatkan respons sesuai dengan petunjuk itu. Tes yang digunakan pada penelitian ini adalah tes tertulis mengenai pembelajaran IPA tentang sifat-sifat cahaya. Tes tertulis ini menggunakan butir soal atau instrument soal berbentuk pilihan ganda pada pembahasan materi sifat-sifat cahaya. (3) Wawancara atau disebut juga interview merupakan suatu cara yang digunakan untuk mendapatkan jawaban dari responden dengan jalan bertanya sepihak. Dikaitkan sepihak karena dalam wawancara ini 
responden tidak diberi kesempatan untuk mengajukan pertanyaan. Wawancara pada penelitian ini dilakukan dengan memberikan pertanyaan kepada guru kelas IV dan siswa untuk menggali informasi mengenai proses pembelajaran IPA pada materi sifat-sifat cahaya dengan menggunakan media video pembelajaran. (4) Dokumentasi dilakukan untuk mendapatkan gambaran yang nyata dan lengkap mengenai kondisi sekolah, kondisi awal sebelum dilakukan tindakan, kondisi selama dilakukan tindakan. Hal ini untuk menunjukan gambaran yang obyektif. Dokumentasi meliputi; silabus, RPP, catatan guru, hasil nilai unjuk kerja, dan foto-foto kegiatan pembelajaran.

\section{Prosedur Analisis Data}

Analisis data yang digunakan dalam penelitian ini adalah analisis kualitatif dan kuantitaif. Analisis kualitatif digunakan untuk mengelola data hasil pengamatan selama proses tindakan siklus yakni melihat dari kelebihan dan kelemahan pada tindakan siklus menggunakan media video pembelajaran, aktifitas dalam analisis data yaitu reduksi data (data reduction), penyajian data (data display), dan penarikan kesimpulan/verifikasi data (verification). Sedangkan analisis kuantitatif digunakan untuk mengolah data hasil belajar siswa untuk mengetahui peningkatan hasil belajar IPA dengan penggunaan media video pembelajaran.

Analisis ini menggunakan statistik sederhana, yaitu dengan cara sebagai berikut: a. Untuk menghitung rata-rata pemahaman materi sifat-sifat cahaya secara klasikal digunakan rumus:

$$
X=\frac{\sum X}{\sum N}
$$

Keterangan:

$\mathrm{X}=$ Nilai rata-rata

$\sum X=$ Jumlah semua nilai siswa

$\sum N=$ Jumlah siswa

b. Untuk menghitung presentase pemahaman materi magnet digunakan rumus:

$$
\mathrm{P}=\frac{\sum T}{\sum N}
$$

Keterangan:

$\mathrm{P} \quad=$ Presentase pemahaman

$\sum T=$ Jumlah siswa yang tuntas belajar

$\sum N=$ Jumlah siswa 


\section{HASIL DAN PEMBAHASAN}

\section{Hasil}

Peneliti melakukan grand tour untuk mendapatkan data pra siklus tentang bagaimana nilai hasil belajar siswa pada materi sifat-sifat cahaya. Kegiatan dilakukan pada tanggal 11 November 2020. Berdasarkan data pra siklus diperoleh informasi bahwa hasil belajar siswa pada materi sifat-sifat cahaya sangat rendah yaitu hanya sebanyak 14 orang siswa (46.7\%) yang memiliki nilai sesuai dengan KKM 70. Hasil wawancara menyatakan bahwa salah satu penyebab rendahnya hasil belajar tersebut adalah karena kurangnya guru menggunakan metode pembelajaran yang variatif dalam memberikan penjelesan materi tentang sifat-sifat cahaya. Adapun data hasil belajar siswa pada saat pra siklus adalah sebagaimana tabel 1 .

Tabel 1. Presentase Data Hasil Belajar Pra Siklus

\begin{tabular}{ccccccc}
\hline No & KKM & Nilai & $\begin{array}{c}\text { Jumlah } \\
\text { Siswa }\end{array}$ & $\begin{array}{c}\text { Jumlah } \\
\text { Nilai }\end{array}$ & Presentase (\%) & Keterangan \\
\hline 1 & 70 & Nilai $\geq 70$ & 14 & 1.000 & $46,7 \%$ & Tuntas \\
2 & 70 & Nilai $\leq 70$ & 16 & 810 & $53,3 \%$ & Belum tuntas \\
& Jumlah & & 30 & 1.810 & $100 \%$ & - \\
& Rata-rata & & - & 60,3 & 60,3 & Kurang Baik \\
\hline
\end{tabular}

Berdasarkan tabel 1, diketahui bahwa masih rendahnya pengetahuan dan pemahaman siswa tentang materi sifat-sifat cahaya pada pembelajaran IPA disinyalir karena berbagai faktor. Diantaranya adalah: masih jarang nya guru menggunakan media pembelajaran pada saat kegiatan pembelajaran berlangsung, hanya sebagian kecil siswa yang telah memiliki sikap belajar mandiri, dan ulet ketika mengikuti kegiatan pembelajaran. Berdasarkan hal tersebut, maka peneliti melakukan penelitian pada siklus I dengan menggunakan media video pembelajaran untuk menjelaskan materi sifat-sifat cahaya.

Empat tahap penelitian yang peneliti lakukan pada saat melakukan siklus I. Keempat tahap tersebut terdiri dari tahap perencanaan, pelaksanaan, observasi, dan refleksi. Pada tahap perencanaan, peneliti menyiapkan instrumen pembelajaran, menyusun Rencana Pelaksanaan Pembelajaran (RPP), menyusun Lembar Kerja Siswa (LKS), lembar observasi, merancang pelatihan soal secara individual dan membuat media video pembelajaran. Siklus I dilaksanakan dengan kegiatan awal, kegiatan inti, dan kegaiatan penutup. Tahap pelaksanaan merupakan tahap implementasi dari RPP yang telah dirancang sebelumnya. Peneliti diberi wewenang untuk melaksanakan kegiatan pembelajaran dan guru sebagai observer. Pada tahap pelaksanaan terdiri dari 3 tahap yaiatu kegiatan awal, kegiatan inti, dan kegiatan penutup.

Selama pembelajaran berlangsung peneliti melakukan pengamatan untuk mengetahui kemampuan siswa dalam mengerjakan soal-soal. Untuk mengetahui kemampuan siswa mengenai pembelajaran IPA tentang sifat-sifat cahaya, kemudian memberikan beberapa soal pilihan ganda sebanyak 10 soal dengan 1 soal memiliki bobot 10 poin. Adapun data hasil belajar siswa pada siklus I adalah sebagaimana tabel 2 berikut ini: 
Tabel 2. Presentase Data Hasil Belajar Siklus I

\begin{tabular}{ccccccc}
\hline No & KKM & Nilai & $\begin{array}{c}\text { Jumlah } \\
\text { Siswa }\end{array}$ & $\begin{array}{c}\text { Jumlah } \\
\text { Nilai }\end{array}$ & $\begin{array}{c}\text { Presentase } \\
(\mathbf{\%})\end{array}$ & Keterangan \\
\hline 1 & 70 & Nilai $\geq 70$ & 22 & 1.700 & $73,3 \%$ & Tuntas \\
2 & 70 & Nilai $\leq 70$ & 8 & 430 & $26,7 \%$ & Belum tuntas \\
& \multirow{2}{*}{ Jumlah } & & 30 & 2.130 & $100 \%$ & - \\
& Rata-rata & & - & 71 & $71 \%$ & Cukup Baik \\
\hline
\end{tabular}

Data pada siklus pertama menyatakan bahwa baru sebanyak 22 (73.3\%) siswa yang sudah memiliki nilai hasil belajar sesuai atau diatas KKM 70. Dengan demikian, diperlukan penelitian lanjutan untuk mencapai kriteria keberhasilan penelitian pada siklus kedua. Hasil refleksi pada siklus pertama menyatakan bahwa ketidaktercapaian nilai hasil belajar siswa sesuai KKM dikarenakan guru yang tidak memberikan appersepsi dan ice breaking terlebih dahulu sebelum kegiatan pembelajaran di mulai, sehingga siswa merasa sangat bosan dan tidak bersemangat saat mengikuti kegiatan pembelajaran. Selanjutnya, siswa tidak diberikan kesempatan untuk membaca terlebih dahulu materi pembelajaran yang akan disampaikan sebelum menyimak video pembelajaran. Selain itu, guru kurang efektif menggunakan waktu pembelajaran yang sudah disediakan.

Pada siklus II, kegiatan penelitian dilakukan melalui kegiatan perencanaan, pelaksanaan, observasi, dan refleksi. Tahap perencanaan, peneliti mempersiapkan perencanaan pembelajaran sebagai perbaikan dari siklus I, pada tahap ini peneliti memperbaiki Rencana Pelaksanaan pembelajaran (RPP), menyiapkan soal tes untuk siklus II, dan membuat video untuk menmbah pengetahuan siswa tentang sifat-sifat cahaya. Pengamatan dilakukan untuk mengetahui situasi pembelajaran dengan pengguanaan video pembelajaran pada pembelajaran IPA tentang sifat-sifat cahaya dengan melihat nilai siswa siklus II. Pada siklus II peneliti menyiapkan tes tertulis untuk mengetahui nilai hasil belajar siswa pada materi sifat-sifat cahaya. Adapun data tentang nilai hasil belajar siswa pada siklus II adalah sebagaimana tabel 3.

Tabel 3. Presentase Data Hasil Belajar Siklus II

\begin{tabular}{ccccccc}
\hline No & KKM & Nilai & $\begin{array}{c}\text { Jumlah } \\
\text { Siswa }\end{array}$ & $\begin{array}{c}\text { Jumlah } \\
\text { Nilai }\end{array}$ & Presentase (\%) & Keterangan \\
\hline 1 & 70 & Nilai $\geq 70$ & 25 & 2.140 & $83,3 \%$ & Tuntas \\
2 & 70 & Nilai $\leq 70$ & 16 & 300 & $16,7 \%$ & Belum tuntas \\
& Jumlah & & 30 & 2.440 & $100 \%$ & - \\
& Rata-rata & & - & 81,3 & $81,3 \%$ & Baik \\
\hline
\end{tabular}

Berdasarkan data pada tebal 3 tersebut diatas, maka sebanyak $25(83.3 \%)$ siswa telah dapat memiliki nilai hasil belajar materi sifat-sifat cahaya sesuai atau diatas KKM 70. Dengan demikian, maka penelitian tindakan kelas dihentikan sampai dengan siklus II, karena pada siklus II nilai belajar siswa telah mencapai kriteria keberhasilan penelitian sebanyak $80 \%$ siswa memiliki nilai hasil belajar di atas KKM. 


\section{PEMBAHASAN}

Ketuntasan dari tes hasil belajar siswa pada siklus I menunjukkan rata-rata kelas yaitu 71 dengan siswa yang tuntas sebanyak 22 siswa dari 30 jumlah siswa kelas IV-A sehingga presentase yang diperoleh yaitu sebesar 73,3\%, karena banyaknya kekurangan atau kelemahan pada siklus I akhirnya masih terdapat beberapa siswa yang belum mencapai Kriteria Ketuntasan Minimum (KKM) yaitu 70. Karena belum memenuhi kriteria ketuntasan hasil belajar yaitu $80 \%$, maka peneliti melanjutkan pada Siklus II untuk dapat meningkatkan hasil belajar siswa.

Pada perbaikan siklus II siswa mulai paham dan mengerti mengenai sifat-sifat cahaya sehingga hasil belajar siswa meningkat. Terlihat dari kenaikan nilai rata-rata kelas pada siklus II yaitu sebesar 81,3 dengan siswa yang tuntas yaitu 25 siswa dari 30 siswa kelas IV-A SDN Kampung Bulak dengan presentase hasil belajar yaitu 83,3\%.

Adapun gambaran tentang perbandingan nilai hasil belajar siswa pada kegiatan pra siklus, siklus I dan siklus II adalah sebagaimana gambar 1.

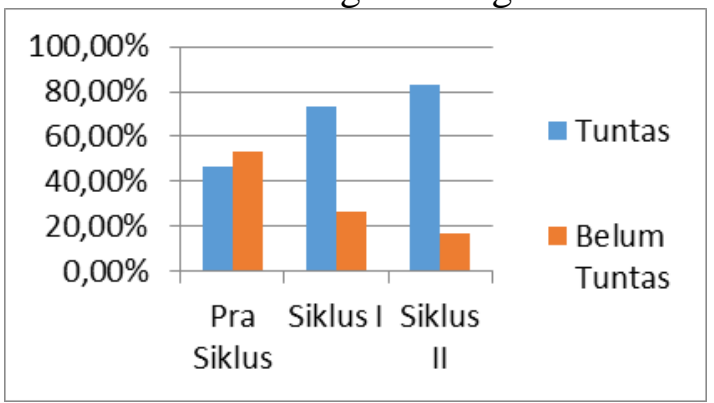

Gambar 1. Perbandingan Nilai Hasil Belajar Pra Siklus, Siklus I dan Siklus II

Berdasarkan data tersebut, maka terlihat peningkatan 26,6\% dari pra siklus ke siklus I, dan $10 \%$ dari siklus I ke siklus II. Dengan demikian hasil penelitian menunjukkan bahwa penggunaan video pembelajaran pada pembelajaran IPA mengenai sifat-sifat cahaya dapat meningkatkan hasil belajar siswa. Penggunaan media video pembelajaran dapat meningkatkan hasil belajar siswa adalah sesuai dengan pendapatnya Simarmata yang menyatakan bahwa: media video pembelajaran sebagai media yang dapat memberikan pesan atau informasi pembelajaran dengan baik yang berisi konsep, prinsip, prosedur, teori aplikasi yang dapat membantu pemahaman seseorang terhadap materi pembelajaran (Simarmata et al., 2020).

Penggunaan media video pembelajaran pada materi IPA memiliki peranan penting agar siswa semakin semangat dalam belajar sehingga nantinya dapat meningkatkan hasil belajar siswa. Penggunaan media video pembelajaran dalam kegiatan pembelajaran memberikan pengaruh yang positif, khususnya terhadap perolehan belajar siswa pada aspek kognitif, rata-rata hasil belajar siswa pada aspek kognitif yang megikuti pembelajaran menggunakan video semakin meningkat pada setiap siklus (Siregar, 2015). Media video pembelajaran yang dikemas secara menyenangkan akan membuat proses belajar mengajar berjalan menyenangkan, apabila proses belajar mengajar yang menyenangkan akan meningkatkan semangat siswa (Arif et al., 2019). Kesediaan dan perhatian siswa yang menggunakan media video pembelajaran untuk menerima materi pelajaran dengan baik serta memperhatikan dengan seksama video yang diputar oleh guru, bersemangat dalam proses pembelajaran, dan lebih menghargai tugas-tugas dari guru sehingga siswa lebih mudah mengingat 
materi pelajaran dan lebih bisa memahami materi pelajaran (Siregar, 2015), (Aliyyah Rusi Rusmiati dan Malia Yesi, 2016).

\section{PENUTUP}

Berdasarkan data hasil penelitian dan refleksi tindakan yang telah dilakukan selama pelaksanaan penelitian sebanyak 2 siklus di Kelas IV SDN Kampung Bulak maka dapat disimpulkan bahwa penggunaan media video pembelajaran dapat meningkatkan hasil belajar siswa. Peningkatan hasil belajar tersebut dapat dibuktikan dengan ketuntasan hasil belajar siswa. Hasil penelitian menyatakan bahwa pada siklus I nilai hasil belajar siswa menunjukkan rata-rata kelas yaitu 71 dengan siswa yang tuntas sebanyak $22(73.3 \%)$ siswa dari 30 jumlah siswa. Pada siklus II siswa mulai paham dan mengerti mengenai sifat-sifat cahaya sehingga hasil belajar siswa meningkat. Terlihat dari kenaikan nilai rata-rata kelas pada siklus II yaitu sebesar 81,3 dengan siswa yang tuntas yaitu 25 (83.3\%) siswa dari 30 siswa kelas IV-A SDN Kampung Bulak.

\section{Daftar Pustaka}

Aliyyah, R., Puteri, F., \& Kurniawati, A. (2017). Pengaruh Kemandirian Belajar Terhadap Hasil Belajar IPA. Jurnal Sosial Humaniora, 8(2).

Aliyyah, R. R., Rasmitadila, Rachmadtullah, R., Widyasari, Mulyadi, D., \& Ikhwan, S. (2019). Using Of Student Teams Achievement Divisions Model (STAD) To Improve Student's Mathematical Learning Outcomes. Journal of Physis: Conference Series, 1175.

Aliyyah Rusi Rusmiati dan Malia Yesi. (2016). Peningkatan Hasil Belajar IPA Melalui Penggunaan Media Audio Visual pada Pembelajaran SIfat-sifat Cahaya. Didaktika Tauhidi, 3, 82-90.

Anugraheni, I. (2017). Analisa Faktor-Faktor yang Mempengaruhi Proses Belajar GuruGuru Sekolah Dasar. Kelola: Jurnal Manajemen Pendidikan, 4(2), 205. https://doi.org/10.24246/j.jk.2017.v4.i2.p205-212

Arif, M. F., Praherdhiono, H., \& Adi, E. P. (2019). Pengembangan Video Pembelajaran IPA Materi Gaya Untuk Siswa Sekolah Dasar. JKTP Jurnal Kajian Teknologi Pendidikan, 2(4).

Astuti, L., Dwi, R., \& Ghoni, A. (2020). Pengembangan Media Pembelajaran Pendidikan Kewarganegaraan Subtema Indahnya Keberagaman Budaya Negeriku Berbasis Video Proshow. Primary: Jurnal Pendidikan Guru Sekolah Dasar, 9(6).

Busyaeri, A., Udin, T., \& Jaenuddin, A. (2016). Pengaruh Penggunaan Video Pembelajaran Terhadap Peningkatan Hasil Belajar Mapel IPA di MIN Kroya Cirebon. Al Ibtida, 3(1).

Hanafy, M. S. (2014). Konsep Belajar Dan Pembelajaran. Lentera Pendidikan : Jurnal Ilmu Tarbiyah Dan Keguruan, 17(1), 66-79. https://doi.org/10.24252/lp.2014v17n1a5

Iriani, E. (2019). Peningkatan Hasil Belajar IPA Siswa Kelas VI Melalui Media Pembelajaran Video pada Tema 6 dna 7 Topik Biologi. Jurnal Pendidikan, 4(1).

Kemendikbud, K. (2003). Undang-Undang Republik Indonesia Nomor 20 Tahun 2003 Tentang Sistem Pendidikan Nasional. Sekretariat Negara Republik Indonesia.

Pangestu, A. D., Samparadja, H., \& Tiya, K. (2015). Pengaruh Minat Terhadap Hasil Belajar Matematika Siswa SMA Negeri 1 Uluiwoi Kabupaten Kolaka Timur. 
Jurnal Penelitian Pendidikan Matematika, 3(2).

Rahayuni, G. (2016). Hubungan Keterampilan Berpikir Kritis Dan Literasi Sains Pada Pembelajaran Ipa Terpadu Dengan Model Pbm Dan Stm. Jurnal Penelitian Dan Pembelajaran IPA, 2(2), 131. https://doi.org/10.30870/jppi.v2i2.926

Sari, Y., MS, Z., Lasha, V., \& Kelengkongan, J. (2020). Peingkatan Kemampuan Berpikir Kritis Melalui Model Auditory, Intektual, Repatition (AIR) Berbentuk Komik di Sekolah Dasar. Refleksi Edukatika: Jurnal Ilmiah Kependidikan, 11(1).

Siahaan, A. (2016). Ilmu Pendidikan dan Masyarakat Belajar. Citapustaka Media Perintis.

Simarmata, J., Hanum, R. A., Situmorang, D., Sitorus, M., \& Lubis, R. A. (2020). Elemen-Elemen Multimedia Untuk Pembelajaran. Yayasan Kita Menulis.

Siregar, J. (2015). Upaya Meningkatkan Hasil Belajar IPA Melalui Penggunaan Video Pembelajaran Bagi Siswa Kelas IV Di SDN I87/IV Kota Jambi. JDP, 8(2).

Susanto, A. (2013). Teori Belajar dan Pembelajaran di Sekolah dasar. Prenadamedia Group. 